\title{
Resource Regions as an Initial Base for Transformation of the Russian Commodity- Based Rental Economy Model
}

\author{
Ludmila Kusurgasheva ${ }^{1, *}$, Lydia Lubyagina ${ }^{1}$, Pawel Stefanek $^{2}$, and Arunas Lapinskas ${ }^{3}$ \\ ${ }^{1}$ Department of Economics, Institute of Economics and Management, T.F. Gorbachev Kuzbass State \\ Technical University, 650000 Kemerovo, Russia \\ ${ }^{2}$ KGHM Polska Miedź SA, Rudna, Poland \\ ${ }^{3}$ Department of Economics, Saint-Petersburg Mining University, 199106 Saint-Petersburg, Russia
}

\begin{abstract}
The article analyzes the current commodity-based rental model of economical growth in Russia. In the conditions when the Russian economy faced serious challenges and risks both within the country and on the outer contour, the question of inertial development possibility and the need to modernize the existing model has become particularly relevant. The aim of the work is to demonstrate the inefficiency, the exhaustion of the commodity-based rental model in relation to growth of opportunities and the futility in relation to the capitalist world-system laws of the development. The article shows that at the present stage the transition from the commodity-based rental model of economical growth to a nationally oriented model of development is possible through the implementation of a new industrialization policy, whereby the resource regions should shift to a sustainable inclusive growth.
\end{abstract}

\section{Introduction}

The state of the Russian economy, despite the fact that official data showed some growth acceleration after their adjustment for 2018, continues to be assessed by specialists as stagnation. Overcoming this negative trend and putting Russia on the path of sustainable dynamic development is a task of paramount importance. Its solution is connected with the need to carry out systemic changes in society, which should alter, first of all, the current model of economic development in Russia. The latter is called in different ways; the most operational term is the "commodity based rental model", which determined the nature of economic growth dynamics in the post-Soviet period and which has now exhausted its potential. Naturally-geographical factors of sectorial labor division determine the localization of the raw material structure in a certain area - within the framework of resource regions. Therefore, it is quite logical to consider them as an initial base for transformation the Russian commodity-based rental economy model and their characteristics not only as a source of problems and issues related to the impact of natural wealth on economic growth and welfare, but also as a potential for transformation.

\footnotetext{
*Corresponding author: klv.eti@kuzstu.ru
} 


\section{Materials and methods}

There is a vast literature on the relationship of the countries resource endowment and economic growth. Despite years of research in this area, there are still no concurrent views as to whether the resource wealth is a "curse" or a boon to the country. However, all research on the effects of resource abundance begins with a statement of an obvious fact that some countries with large reserves of natural resources, especially such as oil and gas, tend to have a lower level of economic development than countries without such resources. For the first time, the thesis on the negative impact of resource abundance ("resource curse") was defined in a paper [1] and has since received many empirical evidence [2-4], including the case of Russia [5-6]. Existing research focuses mainly on identifying the influence channels through which resource abundance undermine the development of a resource-dependent economy. Among the reasons of negative connection between the abundance of natural resources and economic growth, in particular are analyzed: 1) the "Dutch disease" effect, according to which the extractive industries boom has a dismal influence on other (non-resource) industries [7]; 2) decline of investment (including investment in human assets), associated with the volatility of commodity prices [8-11]; 3) rent-oriented unproductive behavior, soaring corruption, deterioration in quality of institutions, and a high probability of civil conflicts [12]. It should be noted that all these significant results were obtained using econometric methods and models. Standard crosscountry models are also used when passing to the analysis of the resources abundance influence for particular regions within the national economic structure, showing similar effects at the regional or local levels.

The presence of a conflicting viewpoint, explaining resource abundance as a boon to the economy ("resource blessing") [13-14], although it cannot be the basis for conclusion of econometric models nonapplicability, indicates their insufficiency. The latter is connected not only with the fact that the model building results are largely determined by the choice of variables, but also by the complexity of the modeling object itself. The two main factors that impart complexity are, firstly, the fundamental uncertainty inherent in a market economy and, secondly, the historically determined place of the national economy in the capitalist world-system. Uncertainty as an objective characteristic of the real world, defined by the complexity and scale of information necessary to economic agents for decision making, as well as the fact that it does not yet exist, it has not yet been created (due to the absence of the fact itself, an event that can still occur as a result of unintentional actions), puts in doubt the realism of econometric models. The second factor necessitates the expansion of analytical base of research by combining various methods, united by a common research program. The systemic paradigm of J. Kornai [15] can act as such general program, according to which society is considered as a unified system requiring complex studies that do not become isolated within private disciplines (economics, political science, sociology). This justifies the use of the world-system approach to the study of the Russian commodity-based rental economy model transformation. World-system analysis allows us to identify and include in the analysis global and macroeconomic factors in the development of resource regions that are not taken into account in papers on econometric modeling of a resource-dependent economy [16].

\section{Results and Discussion}

The size of natural rent is the main characteristic of the entire Russian economy, which is why it is called rental. Almost half of the federal budget revenues are provided by rental incomes, which include, in most of their part, taxes and duties paid by oil and gas companies. Among the external signs of Russian economy rental nature, we can distinguish 
such features as: high dependence of the economy on foreign markets, appearing primarily in dependence of the general state of economy on hydrocarbon prices; structural degradation, appearing in the "weighting", the simplification of the economy structure and deindustrialization; technological gap with developed countries; permanent investment crisis; enterprises dependence on state orders and subsidies; consistently low share of innovation-active enterprises; human capital stagnation; high level of income inequality; low quality of institutions; rent-oriented behavior of economic agents, politicians and officials (high propensity for acts of corruption). The rental-commodity nature of Russian economy is also manifested in the increasing unevenness of the country's spatial development: the regions are actually divided into a developed "center" that plays the role of accumulating and distributing rental incomes and an undeveloped "periphery" consisting of resource regions that generate rent.

The economic system with such characteristics brings to the Dutch disease, which emerging mechanism and development is well known: in a favorable market environment, the commodity-based industries receive additional impulse for expanding their activities, increasing profits and wages, which leads to a decrease in the growth potential of the manufacturing industries and results in deindustrialization of national economy. This approach adequately describes the deepening of regions differentiation, although other factors come into effect at this level, in particular, the infrastructure, production and human potential - all accumulated in the previous period by individual regions.

The Russian economy shows all the symptoms of the Dutch disease. Its background, apparently, was formed as part of the planned Soviet economy, but its mechanism began to work in full force after price liberalization, liberalization of foreign trade and privatization. In other words, the Dutch disease was caused by the shock transition of Russia to a market economy. This raises the question: what were the reasons for choosing such option of transforming the Soviet economic system into a market one? The thesis that this choice was due to political and ideological factors can be considered as proven. The policy choices made by the country's leadership at that time do not fit the logic of purely economic feasibility and efficiency, but can be rationally explained in terms of the ruling classes political interests of the late Soviet society and the "center" countries - privatization, liberalization and "return to the civilized world". Interests, in their turn, are an expression of objective need; in this case, they expressed the need for unlimited expansion (external economic expansionism), which is objectively inherent in the capitalist world-system. On the other hand, the Soviet economy, although it was planned, it can hardly be defined as socialistic. There are strong arguments for the hypothesis of state capitalism. At least, in its depths, in view of the underdeveloped background for the transition to a new social system, a new class formation process was underway, which resulted in the formation of a partyeconomic nomenclature class, which was in fact a new owner of the production means and a "collective entrepreneur." Furthermore, there was a large segment of clandestine capitalism, the subjects of which were various kinds of "shadow merchants". These two classes were the social layer that was objectively interested in restructuring and changing the social system. The interests of both classes, with the flow of resources into the shadow economy, diverged increasingly from the interests of the population majority, but at the same time meet with the ruling class interests of developed countries. As a result, the country had shock 1990s reforms, Russia was reintegrated into the capitalist world-system [16] and, interrupted by the "socialist experiment," the dependence of the Russian economy on the "center" was restored with all the consequences.

Accordingly, the essence of the commodity-based rental model of Russian economy can be defined as rental capitalism of the world economy peripheral zone. The main relation in this system is the center's exploitation of the periphery by means of production, accumulation and redistribution of natural rent, produced in the resource-based industries of 
the peripheral economy. This relationship lays behind the dependence of peripheral economies on developed countries, which appears on the surface of phenomena as their "backwardness" and which is supported by various instruments. The dependence of the periphery countries is the real cause of the "resource curse" and the Dutch disease.

The qualification of Russian economy as rental characterizes its reproduction as a system based on rent. Rent is an additional income (superprofit), resulting from the use of a rare resource in production, that gives the owner of this resource the possibility of monopoly command, both on the terms of ownership and management with its use. The latter serves as the basis for distinguishing various types of rent: mine, land, administrative, intellectual, technological, insider and others. Of all rent types, only natural rent and its varieties are the result of productive activity, yet others are the result of redistributive processes and are essentially a source of fictitious capital. The Russian economy is not just rental, but commodity-based rental, as the main type of rent is natural rent. However, the specific nature of the reproduction process of Russian economy and its institutional originality highlighted above as features of the economy's rental nature, are determined not so much by its commodity-based rental nature, as by the peripheral status in the global economy.

The modern world economy is not a simple group of equal countries, albeit at different stages of development, but a unified system in which individual elements play different roles subject to their place. The dependent periphery role is the maintenance and reproduction of the capitalization system in the "center" countries. Within the framework of the capitalistic world-system there is no exit for dependent countries. Therefore, the current economic model in Russia is not only ineffective, but also non-sovereign, and thus futile.

The situation with inefficiency and futility of the commodity-based rental model would seem to be in contradiction with the fact that the growth rate of the Russian economy is quite high in the pre-crisis years of the first decade of the 21 st century (approximately $7 \%$ per year). However, structural analysis of real GDP growth shows that during this period, the main contribution - almost half - to output growth was provided by external demand. Its significance after the 2008-2009 crisis, and especially after the well-known 2014 events, has seriously decreased. This further demonstrates the dependent nature of Russian economy on external factors and the need for systemic reforms that should change the fundamental society basis, including economy, politics and ideology. Such changes are impossible to apply, relying on neoliberalism as a theory and ideology of the state economic policy. It is impossible either by returning or restoring the command-and-control system in Russia.

Historical experience indicates that Russian economy showed growth rates higher than the world when it was regulated and socially oriented, and at the same time was aimed at ensuring national interests. The intention of building a nationally oriented model of socioeconomic development in the country is being formulated on this basis. Its characteristic features are: the diversity of ownership forms, the combination of market self-regulation institutions and state planning, business initiative and social justice, the priority of the common good over private interests. Such model should be based on adequate productive forces. The latter implies a new industrialization policy aimed at a radical transformation of the technical and technological base through re-industrialization and the transition to new, progressive technological modes.

The place and role of resource-type regions in neo-industrialization is determined by the fact that new industrialization requires significant investments, the source of which, in the current situation, can be the natural rent in the first place. This implies the need for sustainable development of resource regions. The concepts of sustainability and associated with them inclusiveness, balance, and innovativeness of economic growth are extensively and widely discussed in the literature. Выделим главную проблему. We highlight the 
main problem. It lays in determining the priority of social, economic or environmental purposes in determining the development strategy of resource regions. The choice of strategy depends on a number of external and internal factors, among which an important place is occupied by regional policy, which is a part of the state macroeconomic policy. At present day the implementation of the neo-industrialization policy in Russian regions, where it is necessary to systematically create conditions for sustainable inclusive development largely depends on the actions of the government.

\section{Conclusion}

The analysis of the existing in Russia commodity-based rental model has shown its inefficiency, exhaustion from the viewpoint of growth opportunities and the futility of further development within the framework of the center-peripheral structure of world economic relations. Its formation was the result of two laws of nature: firstly, the objectively inherent capitalistic world-system needs for unlimited expansion and, secondly, the need to legalize the property rights of the party and economic nomenclature and the clandestine bourgeoisie of Soviet society. That is why the implementation of 1990s market reforms according to the Washington consensus, the state's withdrawal from the economy with a simultaneous bureaucracy increase in the power, the weakness of market institutions and the "failures" of the state that caused the effects of the resource curse and the Dutch disease, became a reality. The main direction of the commodity-based rental model transformation is the new industrialization, which should be the basis for the formation of a new, nationally oriented development model that meets the objectives of achieving above the world growth rates and changing the institutional structure towards ensuring the country's national economic security and sustainable inclusive development of resource regions.

\section{References}

1. R. Auty, Sustaining Development in Mineral Economies: The Resource Curse Thesis (Routledge, London, 1993)

2. J. Sachs \& A.M. Warner, European Economic Review, 45:4-6, 827 (2001)

3. M. Humphreys, Journal of Conflict Resolution, 49, 508 (2005)

4. F. Van der Ploeg, S. Poelhekke, Journal of Environmental Economics and Management, 60:1, 44 (2010)

5. C.G. Gaddy, B.W. Ickes, Eurasian Geography and Economics, 51:3, 281 (2010)

6. A. Kudrin, E. Gurvich, Russian Journal of Economics, 1:1, 30 (2015)

7. W. Max Corden and J. Peter Neary, The Economic Journal, 92:368, 825 (1982)

8. Ph. Aghion, Ph. Bacchetta, R. Ranciere, K. Rogoff, Journal of Monetary Economics, 56:4, 494 (2009)

9. S. Zhironkin, S. Demchenko, G. Kayachev, M. Ryzhkova, O. Zhironkina, Cluster E3S Web Conf., 41, 04011 (2018)

10. S. Zhironkin, O. Aleshina, V. Gorev, Y. Gunyakov, O. Zhironkina, E3S Web of Conferences, 105, 04001 (2019)

11. M. Prokudina, O. Zhironkina, O. Kalinina, M. Gasanov, F. Agafonov, E3S Web of Conferences, 21, 04003 (2017)

12. H. Mehlum, K. Moene, and R. Torvik, The Economic Journal, 116:508, 1 (2006) 
13. M. Alexeev, R. Conrad, The Review of Economics and Statistics, 91:3, 586 (2009)

14. T. Gylfason, European Economic Review, 45:4-6, 847 (2001)

15. J. Kornai, The System Paradigm (William Davidson Institute at the University of Michigan, Detroit, 1998)

16. N. Osokina, E3S Web of Conferences 41, 04032 (2018) 